Special Issue of the 6th International Congress \& Exhibition (APMAS2016), Maslak, Istanbul, Turkey, June 1-3, 2016

\title{
Environmental Impact on Biopigmentation of Mural Painting
}

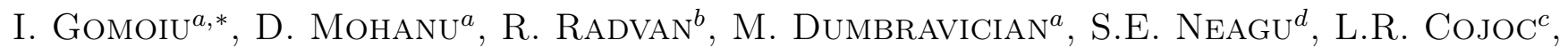 \\ M.I. EnAChe ${ }^{c}$, A. Chelmus ${ }^{b}$ And I. Mohanu ${ }^{d}$ \\ ${ }^{a}$ Department of Conservation Restoration, National University of Arts, Bucharest, \\ 19, Gral Budisteanu, Bucharest, Romania \\ ${ }^{b}$ Center of Excellence for Restoration by Optoelectronic Techniques - CERTO, National Institute for Research \\ and Development in Optoelectronics, 407, Atomistilor Str., Magurele-Ilfov, Romania \\ ${ }^{c}$ Department of Microbiology, Institute of Biology of the Romanian Academy, \\ 296, Spl. Independentei Str., 6 district, Bucharest, Romania \\ ${ }^{d}$ Department of Projects and Research of Binding Materials, CEPROCIM S.A.,
} 6 Blvd Preciziei, Bucharest, Romania

\begin{abstract}
The microclimate monitoring of Humor Monastery, Tismana Monastery and the refectory of Hurezi monastic complex from Romania was performed in order to investigate its effect on the growth of bacteria isolated from infilling mortar. According to the results, microclimate parameters values in Humor Monastery and the refectory of Hurezi monastic complex were similar but specific for each season due to the absence of central heating. Opposite, in Tismana Monastery with central heating, no remarkable differences were noticed during the year. Laboratory results showed that Halobacillus sp., Halobacillus naozhouensis and Nesterenkonia sp. were able to grow in the temperature range between 4 and $37^{\circ} \mathrm{C}$ with optimum at $28^{\circ} \mathrm{C}$, respectively $15^{\circ} \mathrm{C}$. The microclimate parameters from all objectives are favorable for carotenoid producing bacteria which developed true pink biofilms very well attached by the original and infilling mortar as well as by pictorial layer, hiding the real color of mural painting. The microbial origin of pink pigmentation on frescoes from Romanian historical monuments was demonstrated.
\end{abstract}

DOI: 10.12693/APhysPolA.131.48

PACS/topics: 81.70.Fy, 87.10.Vg

\section{Introduction}

Bacterial colonization of historical monuments has structural effects and produces aesthetic changes making sometimes impossible to read or interpret mural painting or reaching the initial aspect even after a high performing restoration. Detachment of pictorial layer, powdering mortar, blue or pink biofilms was identified in different historical monuments from all over the world [1-7]. Wet walls and biofilm allow deposition of the atmospheric particulate materials and biodeteriogens, contributing to biodeterioration over time. Above that, changes in water content (air and walls) are favorable for the saline efflorescences and halophilic bacteria [3]. Microclimate monitoring gives information about causes of damages and prevention of biodeterioration, keeping the monument in a good state of conservation [8-10].

Humor Monastery is located in the village called Mănăstirea Humorului, in the northern part of Romania. It was built in the year 1530 by Petru Rareš and his chancellor Toader Bubuiog and dedicated to the Assumption of the Holy Virgin. The church has been inscribed by UNESCO on its list of World Sites, as one of the most beautiful painted churches of Moldavia.

The execution technique of the decoration is a mixture between a fresco and a secco. The basic colors were

*corresponding author; e-mail: gomoiu@hotmail.com applied on fresh plaster (lime putty and vegetable fibers) and all final details (figures, hands, etc.) were painted later, after the plaster was dried out, using a binder (possible animal glue). There is no central heating in the monastery.

Tismana Monastery is located in the Central-East of Romania and was built by Radu the 1st and his lady Calinichia. The dedication day is also the Assumption of the Holy Virgin. The author of the first painted decoration was Dobromir the Youngest, in 1564. In the 18th century, because the mural paintings were too damaged, they were removed (in the two rooms: the nave and the altar) and new paintings were done. The only room where the old mural paintings remained is the pre nave. The technique used by Dobromir (1564) and later by the new team $(1732,1766)$ is also a combination between a fresco and a secco. There is central heating.

The Monastery of Hurezi is one of the main and also the largest monastic ensembles in central-southern Romania. It dates back to the 17th century (1690-1693), being founded by the ruler Constantin Brancoveanu. In the early eighteen century, a refectory was built in the western side of its axis and in 1705 it was decorated with frescoes following Byzantine tradition. Later on, the eastern and western walls of the refectory as well as the inner side of the niches have been covered by massive over paintings on the lower side of the walls. Also, successive lime washes were applied on part of the wall paintings, on the upper side of the walls and on the eastern and 
western walls. The last restoration of the refectory took place in the years ' 70 s under the coordination of architect Stefan Bals. On this occasion, part of the plaster of the facade has been replaced with a new one, while on the inside, large areas of lacunae at the lower part of the walls have been treated by mortar infilling. There is no central heating.

The paper provides information regarding present status of conservation of the monuments and contributes to elaboration of the scientific strategy for restoration. The microclimate monitoring of Humor Monastery, Tismana Monastery and the refectory of Hurezi monastic complex from Romania was performed in order to establish the proper microclimate for conservation as well as to investigate its effect on the growth of bacteria which produce aesthetical and biochemical changes of pictorial layer, original and infilling mortars.

\section{Materials and equipments}

\subsection{Microclimate monitoring}

HOBO LCD data loggers were placed in different areas and heights in the three monasteries. In Humor Monastery data loggers were fixed in the nave and chamber tombs at $3 \mathrm{~m}$ height (Fig. 1a) and in Tismana Monastery, in altar between 0.5 and $2.0 \mathrm{~m}$ height, in nave up to $2.5 \mathrm{~m}$ height and in pre nave up to $3 \mathrm{~m}$ height (Fig. 1b). In case of the refectory of Hurezi monastic complex, being only one room, the data loggers have been placed on the southern and northern wall at the height of $2.75 \mathrm{~m}$ (Fig. 1c).

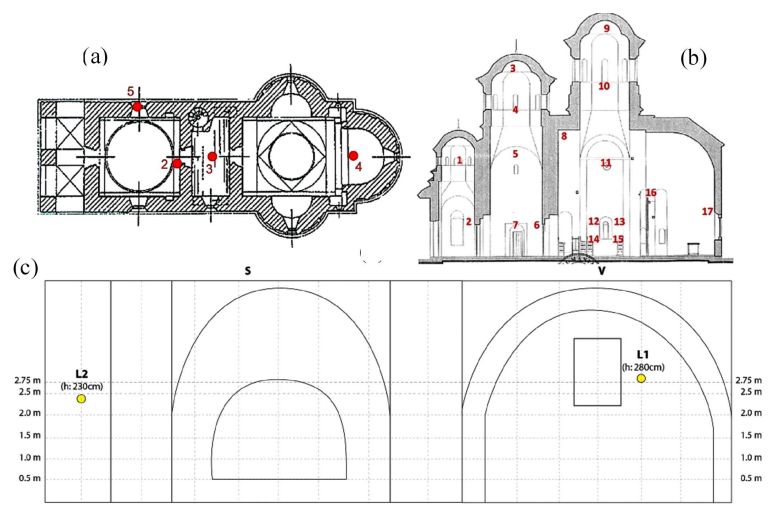

Fig. 1. Positions of the sensors in Humor Monastery (a), Tismana Monastery (b) and refectory (c).

\subsection{Direct examination}

In situ examination had been performed with naked eye and using a hand magnifier. Images of the areas with pink pigmentation had been registered.

\subsection{Observations on the microscope}

Infilling and original mortars as well as pictorial layer were observed in situ with Dino-Lite Digital microscope (LM) and in laboratory with scanning electron microscope (SEM) JEOL JSPM 5200 (Japan), in order to identify the biofilm, bacteria, and their types of arrangements.

\subsection{The influence of temperature on the bacterial growth}

Tests were performed in $\mathrm{MH}$ with $2 \mathrm{M} \mathrm{NaCl}$ nutrient (90 ml) inoculated with $10 \mathrm{ml}$ provided from $24 \mathrm{~h}$ culture prepared in the same nutrient [6]. Incubation took place in static conditions for $96 \mathrm{~h}$ at the following range of temperature: $4{ }^{\circ} \mathrm{C}, 10^{\circ} \mathrm{C}, 15^{\circ} \mathrm{C}, 28^{\circ} \mathrm{C}, 37^{\circ} \mathrm{C}$. Rate of growth had been estimated at spectrophotometer at $660 \mathrm{~nm}$ (BMG LABTECH FLUOStar microplates reader) at each $24 \mathrm{~h}$.

\section{Results and discussion \\ 3.1. Microclimate monitoring}

The results of microclimate monitoring are presented in Table I. The thermal and RH behavior in the refectory of the Hurezi Monastery and Humor Monastery showed similar peaks in all seasons. Lower average of temperature in winter in case of Humor Monastery could be explained by its geographical position (North of Romania) with heavy winters. During the winter condensation inside the pores could take place both in Humor Monastery and the refectory, conducting to breaking of the pore walls, detachment of the upper layers of mural painting, and spreading of biodeteriogens from contaminated areas. Condensation on the surface of mural painting was noticed and could also contribute to the spreading of biodeteriogens. Thermal behavior showed a rising up during the winter depending activities from inside. It was found that in the Humor Monastery, during Christmas time, due to religious services, daily temperature values were between $5^{\circ} \mathrm{C}$ and $20^{\circ} \mathrm{C}$. In the refectory in the same time, daily temperature values were about $7^{\circ} \mathrm{C}$ as a consequence that the only activity was lunch. The absence of central heating clearly influences the microclimate. Tismana Monastery and Hurezi Monastery are placed in the central-southern part of Romania. The central heating in Tismana Monastery kept the temperature between $18^{\circ} \mathrm{C}-23^{\circ} \mathrm{C}$ and $\mathrm{RH}$ between $43-64 \%$ (Table I). According to our results the environment from the three historical monuments is not suitable for conservation of the mural painting. These investigations will be part of a study for the elaboration of a scientific strategy for conservation.

\subsection{Direct examination}

Direct examination revealed pink pigmentation in all monasteries, on the pictorial layer and mortar in areas where pictorial layer was lost, in areas completely covered by efflorescence which became pink. Micro cracks free or full of pink efflorescences were identified, mostly in the lower part of walls. Disaggregation and fragmentation of infilling mortar took place. In Humor Monastery (Fig. 2a), pink pigmentation had been identified in the pre nave up to the height of $0.5 \mathrm{~m}$ and in the chamber tombs up to the height of $0.7 \mathrm{~m}$. In Tismana Monastery (Fig. 2b) pink biopigmentation was very spread: in the porch, pre nave, nave and the altar up to the height of $2.5-3.0 \mathrm{~m}$. In the refectory of the Hurezi Monastery 
TABLE I

Average temperature $\left[{ }^{\circ} \mathrm{C}\right]$ and $\mathrm{RH}[\%]$ in different seasons at the Humor Monastery, Tismana Monastery and refectory of Hurezi monastic complex.

\begin{tabular}{c|c|c|c}
\hline \hline & Humor & Tismana & Hurezi refectory \\
\hline \multicolumn{3}{c}{ winter } \\
\hline$T_{m}$ & 1.16 & 17.93 & 5.26 \\
$\mathrm{RH}$ & 67.79 & 42.9 & 63.31 \\
\hline \multicolumn{3}{c}{ spring } \\
\hline$T_{m}$ & 10.3 & 20.44 & 10.09 \\
$\mathrm{RH}$ & 67.9 & 48.4 & 61.68 \\
\hline \multicolumn{3}{c}{ summer } \\
\hline$T_{m}$ & 20.41 & 22.88 & 20.62 \\
$\mathrm{RH}$ & 70.22 & 64.9 & 62.59 \\
\hline \multicolumn{3}{c}{ autumn } \\
\hline$T_{m}$ & 13.12 & 18.71 & 14.89 \\
$\mathrm{RH}$ & 64.13 & 57.8 & 65.00
\end{tabular}

(a)

(b)

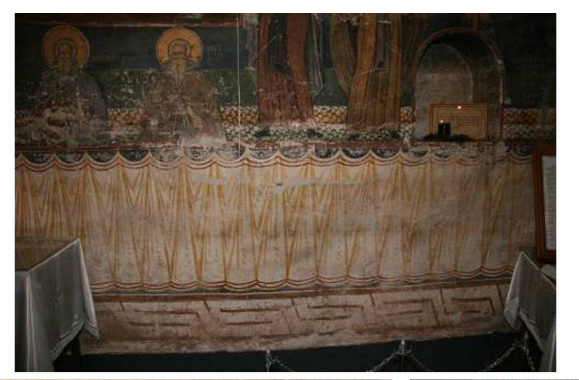

(c)

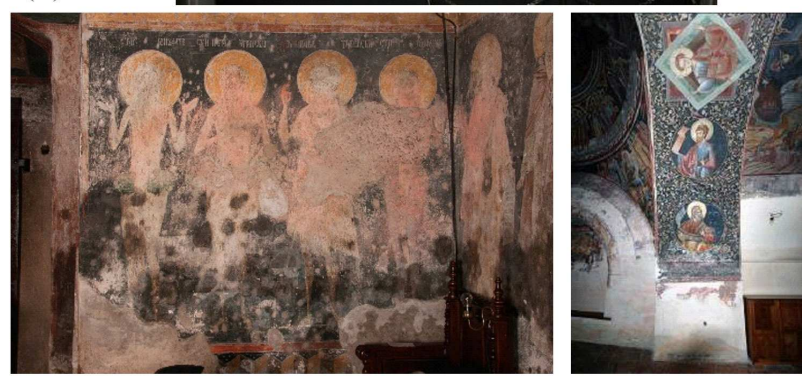

Fig. 2. Pink pigmentation in Humor Monastery - pre nave (a), Tismana Monastery - nave (b) and refectory of the Hurezi monastic complex — eastern arch (c).

(Fig. 2c) pink pigmentation was found on all walls up to $0.30 \mathrm{~m}$, except the northern wall, where mainly into the niche it was identified up to the height of $1.8 \mathrm{~m}$.

\subsection{Optical microscope examinations}

Optical microscope examinations showed pink pigmentation on the original and infilling mortar (Fig. 3a and b) as well as on the pictorial layer (Fig. 3b) as compact or isolated pink masses entering also inside of micro cracks. Optical microscope (LM) examination confirmed thick layers of efflorescences colored in pink. When the biofilm was thin, its continuity was interrupted by salt crystals during the process of efflorescence formation; then they became completely pink due to the growth of halophilic bacteria which produce carotenoid pigments. The proof that pink pigmentation had biological origin came from SEM micrographs where round shaped bacteria were distributed in chains or in groups developed thin or thick biofilms (Fig. 3c). Extracellular polymeric substances (EPS) were detected around the cells forming biofilm. Roldán et al. [11], Wierzchos and Ascaso [12] suggested that the extracellular polysaccharides, proteins, lipids and enzymes induce mechanical effect on the mortar and pictorial layer in favorable environment (available water and temperature). Isolated mineral grains had been put in evidence on SEM micrographs showing that bacteria are involved in disaggregation of the substrate most probably due to their ability to produce organic acids. Electron microscopy proved also that bacteria are able to grow inside the pores with the consequence of their clogging; could be also taking place the breaking of the pore walls and detachment of the pictorial layer. Both biofilm and clogged pores avoid evaporation of water from the walls. Salt efflorescences themselves produce additional pressure in the pores and on the surface, leading to cracking and detachment of the materials [13]. Isolated bacteria were identified through molecular techniques as Halobacillus sp., Halobacillus naozhouensis and Nesterenkonia sp. (yet unpublished results). Clearly the process of pink biopigmentation started in the past and in present is under the progress in connection with environmental conditions. Laiz et al. [14] in three different sampling sites (Sevilia and Postumio tombs in the Roman Necropolis of Carmona, Spain) and Imperi et al. [5] in the Crypt of Original Sin, found the bacterial aetiology of rosy discoloration. Also, Pińar et al. identified the same morphology at the Catherine Chapel of Castle Herberstein [4].
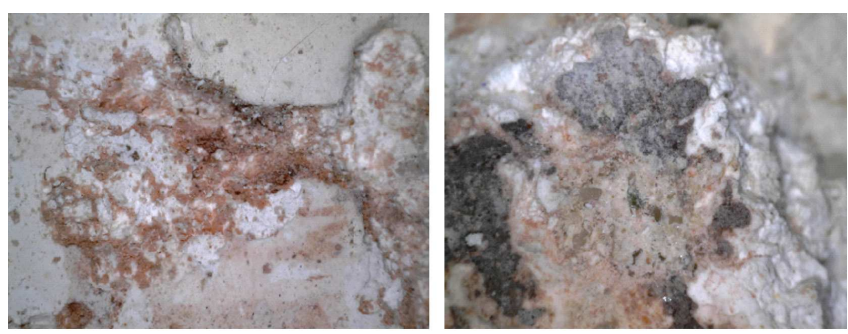

(a)

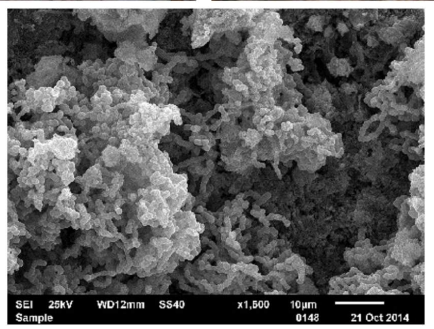

(b)

Fig. 3. LM (a,b) and SEM (c) micrographs of pink biofilm, shape and arrangement of bacteria.

\subsection{The influence of temperature on the bacterial growth}

The influence of temperature on the bacterial growth is shown in Fig. 4. Bacteria Halobacillus sp, Halobacillus 


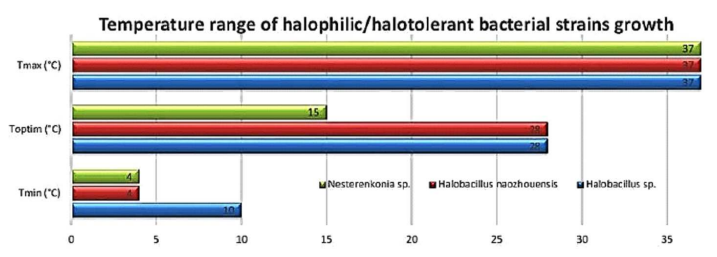

Fig. 4. The rate of bacterial growth at different temperature range.

naozhouensis, and Nesterenkonia sp. were able to grow between $40^{\circ} \mathrm{C}$ and $37^{\circ} \mathrm{C}$ with optimum at $28^{\circ} \mathrm{C}$ for the first two and at $15^{\circ} \mathrm{C}$ for the last one. The growth took place with different rates, specific for each species and in accordance with temperature and $\mathrm{RH}$ values.

The microclimate monitoring and temperature range of bacterial growth clearly showed that inside of the monuments there are favorable conditions for biological growth during the entire year with maximum reached in summer in all investigated case studies. The rate of bacterial growth was lower in winter in Humor Monastery and in refectory of the Hurezi Monastery. Opposite, in Tismana Monastery bacterial growth took place with a higher rate the entire year because central heating improved environmental conditions. Walls structure as well as the support of mural paintings was also favorable for bacterial growth. The adhesion of bacterial cells is more efficient on the rough substrate containing the aggregates sized of $0.2-2.0 \mathrm{~mm}$ in Humor Monastery or $0.3-44 \mathrm{~mm}$ in Tismana Monastery. Comparable size of aggregates in Tismana Monastery and refectory of the Hurezi monastic complex could explain the high distribution of pink biopigmentation.

The rate of colonization of mortar and pictorial layer depends on the physical-chemical properties of the substrate. The changes of capillarity water uptake of the porous mortar material produced by microbial biofilm have as a consequence the alteration in the water-vapor diffusion as well as the bacterial movement. The water and moisture retention in brick, stones and mortar enhance physical decay in connection with the microclimate of all historical monument analyzed.

\section{Conclusion}

Microclimate monitoring is useful for understanding the changes of color in situ, prevention of salts crystallization as well as biological growth. It showed the impact of temperature and $\mathrm{RH}$ on the state of conservation of mural painting as well as on the biodeterioration. Pink pigmentation was produced by Halobacillus sp., Halobacillus naozhouensis, and Nesterenkonia sp. which developed thin or thick biofilm depending on microclimate conditions from each historical monument. The rate of bacterial growth is strongly influenced by variations of temperature and $\mathrm{RH}$. Infilling and original mortars as well as pictorial layer contain organic compounds either from initial technique or as accumulated deposits in time which are used as nutrient for the growth of bacteria and colonization of the substrate. Biological characteristics of Halobacillus sp., Halobacillus naozhouensis, and Nesterenkonia sp. explain their involvement in the colonization of substrate and producing carotenoid pigments involved in pink discoloration. Preventing of salts crystallization could stop pink biopigmentation.

\section{Acknowledgments}

This research has been carried out with financial support of the National Research Program Parteneriate in domenii prioritare - PNII, MEN - UEFISCDI, project no. PN-II-PT-PCCA-2013-4-0660 and PN-II-PT-PCCA2011-3.2-0356.

\section{References}

[1] K. Rajkowska, A. Otelewska, A. Kozirog, M. Piotrowska, P. Nowicka-Krawczyk, M. Hachłka, G.J. Wolski, A. Kunicka-Styczyńska, B. Gutarowska, A. ŻydzikBialek, Ann. Microbiol. 64, 799 (2014).

[2] I. Gomoiu, D. Mohanu, I. Mohanu, A. Luca, M. Seclaman, O.-H. Barbu, The Reavens Stone - An Interdisciplinary Study, UNARTE Ed., Bucharest 2010.

[3] C. Milanesi, F. Baldi, S. Borin, R. Vignani, F. Ciampolini, C. Faleri, M. Cresti, Int. Biodet. Biodegrad. 57, 168 (2006).

[4] G. Pińar, J. Ettenauer, K. Sterflinger, in: The Conservation of Subterranean Cultural Heritage, Ed. C. Saiz-Jimenez, Taylor \& Francis Group, London 2014, p. 113.

[5] F. Imperi, G. Caneva, L. Cancellieri, M.A. Ricci, A. Sodo, P. Visca, Environ. Microbiol. 9, 2894 (2007).

[6] A. Ventosa, M.C. Gutierrez, M.T. García, F. RuizBerraquero, Int. J. Syst. Bacteriol. 39, 382 (1989).

[7] S.Köcher, V.Müller, in: Halophiles and Hypersaline Environments, Eds. A. Ventosa, A. Oren, Y. Ma, Springer, Berlin 2011, p. 303.

[8] F. Becherini, A. Bernardi, M.C. Di Tuccio, A. Vivarelli, L. Pockelč, S. De Grandi, S. Fortuna, A. Quendolo, J. Cult. Herit. 18, 375 (2015).

[9] D. Camuffo, A. Bernardi, Stud. Conserv. 40, 237 (1995).

[10] E. Grinzato, P.G. Bison, S. Marinetti, J. Cult. Herit. 3, 21 (2002).

[11] M. Roldán, C. Ascaso, J. Wierzchos, Appl. Environ. Microbiol. 80, 2998 (2014).

[12] J. Wierzchos, C. Ascaso, 46, 446 (1998).

[13] G. Pińar, D. Piombino-Mascali, F. Maixner, A. Zink, K. Sterflinger, FEMS Microbiol. Ecol. 86, 341 (2013).

[14] L. Laiz, A.Z. Miller, V. Jurado, E. Akatova, S. Sanchez-Moral, J.M. Gonzalez, A. Dionísio, M.F. Macedo, C. Saiz-Jimenez, Naturwissenschaften 96, 71 (2009). 